\title{
Semmelweis vidéki elismerése 1861-ben - tiszteleti tagsága a Bars megyei Gyógyászati Egyletben
}

\author{
Kiss László dr.
}

1860 októberében, 1861-es dátummal, megjelent Semmelweis könyve, a „Die Aetiologie, der Begriff und die Prophylaxis des Kindbettfiebers”. Semmelweis egy példányát mellékelte a Helytartótanácshoz írt felterjesztéséhez. Arra kérte az „ország legfőbb kormányszékét”, hasson oda, hogy az általa ajánlott „óvszer” - klórvizes kézmosás - „országszerte, legkivált a kórházaknál általánosíttassék". A Helytartótanács kikérte az orvostanári testület véleményét. E vélemény nemcsak pozitív volt, de a tanári kar még bővített is a javaslaton: az óvszert alkalmazni kell a magángyakorlatban is. $\mathrm{E}$ vélemény alapján 1862. július folyamán a Helytartótanács valamennyi törvényhatóságot felszólította Semmelweis óvszerének bevezetésére [1].

Úgy tünt tehát, hogy Semmelweis - legalábbis itthon - révbe ért. Nemcsak a Semmelweis barátja, Markusovszky Lajos által szerkesztett Orvosi Hetilap, hanem a konkurensnek számító Gyógyászat - Poór Imre lapja - is megbecsüléssel ír a pesti szülészprofesszorról és tanításáról. A nyomtatott elismerések mellett kevésbé ismertek az egyéb fórumokon, illetve a Pest-Budán kívül megnyilvánuló pozitív visszajelzések.

Az egyik legfontosabb fórum, amely alkalmas volt akár az egész országot érintő egészségügyi problémák megtárgyalására is, a Magyar Orvosok és Természetvizsgálók Vándorgyúlése volt. Az 1841-ben indult mozgalmat - hasonlóan a Bugát és Flór által szerkesztett Orvosi Tár laphoz, illetve a megyei orvosegyletekhez - a szabadságharc leverése után az osztrák hatóságok betiltották. Az újraengedélyezést követően, 1863-ban Pesten találkozott a IX. Vándorgyưlés 438 résztvevője [2]. A résztvevők névsorában ott találjuk Semmelweis nevét is - előadást azonban nem tartott. A következő évben keletre „vándoroltak” az orvosok és természetvizsgálók: a találkozó színhelye Marosvásárhely (Târgu Mureş, Románia) volt. A nem kis távolság és a korántsem ideális utazási körülmények ellenére 491 beiratkozott résztvevője volt az 1864. augusztus 22. és szeptember 2. között megtartott jubileumi, X. Vándorgyúlésnek. Semmelweis nincs a beiratkozottak közt, neve azonban az egyik leggyakrabban emlegetett név lehetett a Maros partján.
A vándorgyúlések érdemi munkáját a szakosztályokban elhangzott előadások, bemutatók képezték. Marosvásárhelyen - mint általában az egyéb helyszíneken is legaktívabbak az „orvos-, sebész-, élet- és boncztani szakosztály" tagjai voltak. E szakosztályban tartotta meg előadását halasi Spányik József, Csíkszék alorvosa. A vándorgyúlésről kiadott Munkálatokban megtalálható az említett szakosztályi ülés jegyzőkönyve - ebből idézek: „Halasi Spányik József, Csíkszék alorvosa a gyermekágyi lázról értekezik, két esetet leírván, melynél mindkettőnél kiderült, hogy a kórt rothadt állati anyaggal történt fertőzés okozta... Legkétségbevonhatatlanabb Semmelweisz (!) tanár azon állítása, miszerint a gyermekágyi láz rothadt állati anyag által mindig fertőzés útján idéztetik elő, s így helytelen a gyermekágyi-láz elnevezés: helyesebb volna azt hullamérgezés vagy genyláz névvel nevezni" [3: 57. o.].

Sajnos, Spányik értekezése csak „tudomásul vétetett”, de nem találtatott érdemesnek a Munkálatokban való megjelentetésre. Nem részletezi Spányik előadását a csíkszéki (ma Hargita megye, Románia) egészségügy történetét feldolgozó kötet sem, csupán megjegyzi, hogy Spányik „Maizner János kolozsvári orvostanár mellett Semmelweis Ignác erdélyi híve volt” [4]. Még inkább sajnálhatjuk, hogy a résztvevők névsorában a 280.-ként feltüntetett „Markusovszky Lajos o. tudor, Pest”, a szeptember elsején tartott harmadik szakülés alelnökének előadását sem olvashatjuk. Erről a jegyzőkönyv csak ennyit ír: „Markusovszky Lajos tr., a mai gyúlés egyik alelnöke ... a sebészi és gyermekágyi láz azonosságának felismerésérôl és roppant befolyásáról a sebesültek halálozásának csökkentésére ... értekezett. Nagy érdekkel hallgatott szóbeli előadása kedvesen fogadtatott" [3: 60. o.].

Mint említettem volt, Semmelweis neve nem található a résztvevők listáján. Valószínü az is, hogy barátja előadásáról is csak „szóbelileg” értesülhetett, annak hazaérkezte után, hiszen a Munkálatok csak egy évvel később, 1865-ben jelent meg. (Semmelweis 1865-ben hunyt el.)

Kevésbé tekintélyes fórumai voltak a kor orvosainak az egyes megyékben újrainduló „orvos/gyógyászati egyle- 
tek”. A Gyógyászat 1871-ben közli: „Magyarhonban máig 21 orvosegylet van megalakulva: a barsi, békésmegyei, biharmegyei, borsodi, budapesti, debreceni, egri, győri, gömör-kishontmegyei, jászkerületi, kolozsvári, mármarosi, pozsonyi, rozsnyói, selmeci, sopronmegyei, szatmári, szabadkai, szepesi, turóci és zemplénmegyei” [5].

A „barsi” egylet nemcsak az ábécérendben közölt listán szerepel előkelő helyen, hanem a megalakulás sorrendjét tükröző felsorolásban is. A Bach-korszakban is engedélyezett, 1837-ben alapított Pest-Budai Orvosegyesület, illetve az 1856-ban alakult, ám kezdetekben csak német nyelvü pozsonyi „Verein für Naturkunde zu Pressburg" mellett a Bars megyei Gyógyászati Egylet (BGYE) volt valószínúleg az elsô magyar nyelvú megyei egylet az abszolutizmus korát követően. Az 1861-ben alakult BGYE története még kutatóira vár, annál inkább, mivel sem a szlovák [6], sem a magyar szakirodalom „nem tud" létezéséról. Amit tudunk róla, az annak köszönhető, hogy a kezdeti években az egyletnek kitűnő kapcsolata volt a Poór-féle Gyógyászattal. A lap nemcsak a negyedévenként tartott ülések jegyzőkönyveit közölte, hanem a BGYE által kidolgozott, közegészségügyi problémákra reagáló állásfoglalásaikat is [7].

A témánk szempontjából fontos közlésre is a Gyógyászatban találtam rá. A valószínúleg az egylet titkára, Boleman Ede, lévai gyógyszerész által beküldött tudósítás arról is hírt ad, hogy az 1861. március 8-án, a megyeszékhelyen, Aranyosmaróton (ma: Zlaté Moravce, Szlovákia) az igazgatóság megválasztását követően: „Hogy hálateljes elismerését az egylet a gyógyászati tudományok - kiváltképpen hazai - bajnokai iránt kifejezhesse, még e gyưlésen egyletünk tiszteletbeli tagjaivá megválasztattak: Sauer, Balassa, Oppolzer, Poor, Than K., Markusovszky, id. Zlamál Vilmos, Semmelweisz (!), Lippay tr. urak" [8]. Ragyogó névsor, a gyógyászat valódi bajnokai a XIX. század derekán! Talán csak Johann von Oppolzer (1808-1871), a cseh származású, előbb prágai, lipcsei, majd bécsi belgyógyászprofesszor „lóg ki” a sorból. Pesti kollégája, Samer Ignác (1801-1863) nemcsak a belgyógyászat tanára, hanem 1861-ben ő az országos fóorvos (protomedikus) is. Balassa János (1814-1868) a sebészet, idősebb Zlamál Vilmos (1803-1886) az állatgyógyászat, Lippay Gáspár (1809-1895) a szemészet professzora, Than Károly (1834-1908) a kémia előadója, később tanára Pesten. A „bajnokok” közé sorolták a két lapkiadó-szerkesztőt, Markusovszkyt és Poórt is.

Nem tudjuk, ki kezdeményezte Semmelweis megválasztását - valószínúleg az egylet „spiritus movense”, Brach Ferenc (1821-1894), lévai orvos. Az orvosi tanulmányait Pesten kezdő, majd Bécsben 1846-ban, „a sömörről” (...de herpete) írt disszertációjával befejező [9] Brach személyesen ismerhette a két szülészeti klinika halálozásának különbségén töprengő bécsi tanársegédet.
A szakirodalomban nem találtam utalást Semmelweis ilyen jellegú megbecsülésére. Nem volt módomban kutatni a történelmi Bars (szlovák nevén: Tekov) vármegye levéltárában, így nem tudom, reagált-e Semmelweis - esetleg más valaki a tiszteletbeli tagok közül - a BGYE nemes gesztusára. Megválasztása mindenképpen arra utal, hogy a (fel)vidék orvosai ismerték Semmelweis nevét és „bajnokhoz” méltó hozzájárulását a gyógyászat fejlődéséhez. A Magyar Tudományos Akadémia IX. Osztály Jövőkutatási Bizottsága 2015. június 12-i ülésén hangzott el: „... Semmelweis igazságát és tanítását a halálát követő évtizedek, tehát a jövő kutatómunkája értékelte valójában...”[10]. Ezen „posztumusz” értékelés első fecskéjének tekinthetjük a Bars megyei tiszteleti tagságot.

\section{Irodalom}

[1] Benedek I. Semmelweis and his era. [Semmelweis és kora]. Gondolat Kiadó, Budapest, 1967. [Hungarian]

[2] Szőkefalvi-Nagy Z. The Congresses of the Hungarian Physicians and Naturalist (1841-1933). [A Magyar Orvosok és Természetvizsgálók Vándorgyúlései (1841-1933).] Orvostörténeti Közlemények. Communicationes de Historia Artis Medicinae 1969; 50: 45-56. [Hungarian]

[3] Szabó J. (ed.) Historical notes of the 10th summit of Hungarian Physicians and Naturalists in Marosvásárhely. [A Magyar Orvosok és Természetvizsgálók... Marosvásárhelyt tartott X. Nagygyúlésének történeti vázlata és munkálatai.] Emich Gusztáv, Pest, 1865. [Hungarian]

[4] Bachner I, Balog L, Málnási L. Chapters from the history of healthcare in Csik (county Hargita). [Fejezetek a csíki egészségügy történetéből.] Alutus Kiadó, Csíkszereda, 2008; p. 73. [Hungarian]

[5] Gyógyászat, 1871; 11: 16.

[6] Pekařová K. Natural-science and medical societies acting in the teritory of the present Slovakia (1850-1918). [Prírodovedné a lekárske spolky na území Slovenska (1850-1918).] Univerzitná Knižnica, Bratislava, 2010. [Slovak]

[7] Kiss L. Democracy vs centralization in the Hungarian system 1863-1868. [Demokrácia kontra centralizáció az egészségügyben anno 1863-1868.] Orv Hetil. 1992; 133: 623-624. [Hungarian]

[8] sz.n. Bars County Medical Society. [A Bars megyei Gyógyászati Egylet.] Gyógyászat 1861; 1: 645. [Hungarian]

[9] Dörnyei S. Old Hungarian medical dissertations, Vol. 3. [Régi magyar orvosdoktori értekezések. Harmadik kötet.] Borda Antikvárium, Zebegény, 2010; p. 54. [Hungarian]

[10] Schmidt P. Ignác Fülöp Semmelweis' oeuvre is appreciated especially by the future generations - value of the outstanding doctor-scientist' Life Achievement from the science' point of view Hungarian Scientific Academy. [Semmelweis Ignác Fülöp tevékenységét a jövő nemzedéke tudta csak igazán értékelni - a kiváló orvos tudós munkásságának értékei a tudomány szemszögéből.] Orv Hetil. 2015; 156: 2090-2092. [Hungarian]

(Kiss László dr., SK-93 008 Csilizradvány 284., Szlovákia e-mail: kiss.agi@panelnet.sk) 